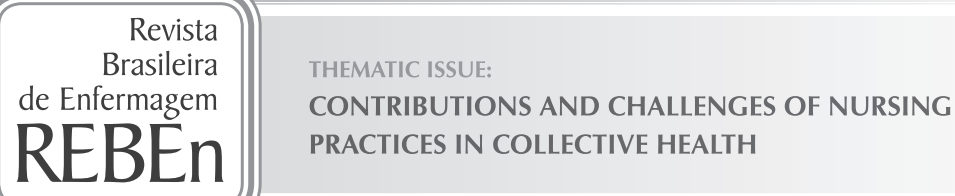

\title{
Work and Leprosy: women in their pains, struggles and toils
}

\author{
Trabalho e hanseníase: as mulheres em suas dores, lutas e labutas \\ El trabajo y la lepra: las mujeres en sus dolores, luchas y esfuerzos
}

\begin{abstract}
Marcela Gonçalves', Michely Aline Rodrigues do Prado', Simone Santana da Silva", Karen da Silva Santos", Priscila Norié de Araujo", Cinira Magali Fortuna"
\end{abstract}

' Universidade de São Paulo, Escola de Enfermagem de Ribeirão Preto. Ribeirão Preto, São Paulo, Brazil. II Universidade de São Paulo, Escola de Enfermagem de Ribeirão Preto, Postgraduate Program in Nursing in Public Health. Ribeirão Preto, São Paulo, Brazil.

How to cite this article:

Gonçalves M, Prado MAR, Silva SS, Santos KS, Araujo PN, Fortuna CM. Work and Leprosy: women in their pains, struggles and toils. Rev Bras Enferm [Internet]. 2018;71(Suppl 1):660-7. [Thematic Issue: Contributions and challenges of nursing practices in collective health] DOI: http://dx.doi.org/10.1590/0034-7167-2017-0598

\section{Submission: 08-30-2017 Approval: 11-27-2017}

\begin{abstract}
Objective: To analyze the interference of leprosy in women's life regarding work and daily life activities. Method: Exploratory qualitative study developed from semi-structured interviews and with the use of field diaries. The strategy of the organization of data was a thematic analysis of content and referential of the work process in health and gender. Results: The themes presented are: "The leprosy pains", "Changes with the disease and adaptation at work and activities" and "Being a woman with leprosy". On them, we present the aspects that changed in women's life from the leprosy, especially regarding work and daily activities. Beyond physical limitation, there are impacts on social relations and above all on formal work, there may even be dismission. Final considerations: In women affected by leprosy, work and daily activities are directly affected; this deepens the social difficulties and requires attention of health professionals. Descriptors: Leprosy; Women; Job; Neglected Diseases; Women's Health.
\end{abstract}

\section{RESUMO}

Objetivo: Analisar a interferência da hanseníase na vida de mulheres em relação ao trabalho e atividades de vida diária. Método: Estudo qualitativo exploratório desenvolvido a partir de entrevistas semiestruturadas e com uso de diário de campo. A estratégia de organização dos dados foi análise temática de conteúdo e referencial do processo de trabalho em saúde e gênero. Resultados: Os temas apresentados são: "As dores da hanseníase", "Mudanças com a doença e adaptações no trabalho e nas atividades" e "Ser mulher com hanseníase". Neles, apresentamos os aspectos que mudaram na vida das mulheres a partir da hanseníase, especialmente com relação ao trabalho e às atividades diárias. Além da limitação física, há impactos nas relações sociais e sobretudo no trabalho formal, podendo haver inclusive demissão. Considerações finais: Em mulheres acometidas pela hanseníase, o trabalho e as atividades diárias são diretamente afetados; isso aprofunda as dificuldades sociais e requer atenção dos profissionais de saúde. Descritores: Hanseníase; Mulheres; Trabalho; Doenças Negligenciadas; Saúde da Mulher.

\section{RESUMEN}

Objetivo: Analizar la interferencia de la lepra en la vida de mujeres en relación al trabajo y las actividades de la vida diaria. Método: Estudio cualitativo exploratorio desarrollado a partir de entrevistas semiestructuras y con el uso de diario de campo. La estrategia de organización de los datos fue el análisis temático de contenido y referencial del proceso de trabajo en salud y género. Resultados: Los temas presentados son: "Los dolores de la lepra", "Cambios con la enfermedad y adaptaciones en el trabajo y en las actividades" y "Ser mujer con lepra". En ellos, presentamos los aspectos que cambiaron en la vida de las mujeres a partir de la lepra, especialmente con relación al trabajo y a las actividades diarias. Además de la limitación física, hay impactos en las relaciones sociales y sobre todo en el trabajo formal, con posibilidad incluso de dimisión. Consideraciones finales: En mujeres contagiadas por la lepra, el trabajo y las actividades diarias son directamente afectados, lo que profundiza las dificultades sociales y requiere atención de los profesionales de la salud.

Descriptores: Lepra; Mujeres; Trabajo; Enfermedades Olvidadas; Salud de la Mujer.

CORRESPONDING AUTHOR Cinira Magali Fortuna E-mail: fortuna@eerp.usp.br




\section{INTRODUCTION}

This study approaches aspects related to work, leprosy and female gender. The leprosy, neglected and millenarian considered disease, illustrates the close relation between life conditions and the process of health and disease. The work issue is taken as an aspect that allows us to understand the social relations and the way that society produces and reproduces, just like gender.

Nursery and health can deal with diseases like leprosy considering it just as another pathology that affects nerves and skin and can produce disabilities, interfering with activities and work, affecting productivity and self-esteem. But it can also take it as an important analyzer that exposes the conditions of social inequality on which process it the transmissibility, the control, the biopower, the imposition of values in the face of this disease, which, in theory, could already be controlled in Brazil. The analyzers are elements that allow us to give visibility and credibility to the contradictions of the institutions ${ }^{(1)}$.

It must be considered that although the disease is curable in all its forms, the challenge in its confrontation is not found in the biological, but in the social and cultural sphere, after all it affects the poorest regions of the world, fact that proves its association with social inequalities ${ }^{(2-4)}$. Because it is transmitted through the airways, anyone, regardless of social class, may become ill, but the less favored population has a higher incidence, because their inadequate living and health conditions favor the contamination and dissemination of the mycobacteria ${ }^{(5)}$.

The ways and conditions of coping with this disease in different social classes is also different by access to health services, work, information, adequate housing conditions, social support network, among other aspects.

Leprosy is among the diseases classified as Neglected Diseases, which means low interest of the pharmaceutical industry, equipment industry and technologies in this type of pathology, since it affects poor people in poor and developing countries. This term includes the processes that reaffirm the existing social inequality, which conditions the poorest people to their exclusion condition ${ }^{(6-7)}$.

The impact caused by the disease interferes with people's daily lives; because of leprosy, they live the constant threat of prejudice, suffering, abandonment, deformities and psychosocial problems ${ }^{(2-3)}$. However, when it affects people already subjected to conditions of inequality, such as women, taking into account their difficulties due to gender, their effects can be even more shocking.

In terms of gender and health, in general, there is a marked difference between men and women in what concerns specific needs, as well as access to services and a search for health protection. Regarding the relationship between gender and people affected by leprosy, studies show ${ }^{(2,8-9)}$ that the disease has the potential to constitute a trigger for changes in family structure. It can even put the affected woman at a greater disadvantage, not only because of the historical gender inequality that women already experience daily, but also because it is a stigmatized disease.

Another relevant aspect regarding leprosy is its association with what is ugly. The ideals and standards of beauty, strongly incorporated in Brazilian society, and charged by and by women, are called into question when they are affected by leprosy. Realizing their smeared body and marked by a disease stigmatized in society unfolds in suffering and anguish for them, affecting their body image, after all, at first, they understand that they are out of the standard that the social environment considers beautiful, ceasing to be the mother, daughter, wife of other ${ }^{(3,10-11)}$.

At work, the impact of leprosy diagnosis is directly associated with exposure to the sensation of danger experienced by both the affected and the others. Faced with this fact, people with leprosy are vulnerable to unemployment, especially when there is a manifestation of the disease, making it public in the workplace $^{(2)}$. Relevant to value the discussion about work, especially in what involves actions beyond work as "profitable activity".

In case of women, still today considered the central figure in domestic services, it develops double and triple working days. Therefore, explaining work as activities of daily living is also worth highlighting. A study ${ }^{(12)}$, in an attempt to give visibility to the debate, exemplifies a woman who performs the activities of daily life, from the reproductive sphere, and compares it to a mill: "it is an entire mill concentrated in one person, every millimeter of its body, your brain, your affection, perform functions that would occupy an entire company with various specialists. Despite this reflection on the part of the author, it is emphasized that the understanding on the part of these women about their own work is distorted, is permeated by a feeling of devaluation, of non-recognition, for understanding it as actions associated with activities of financial income. We consider the comparison with the mill revealing the productivity expectation of labor in the capitalist mode of production.

Work is here considered as a process of relationship between man and nature, where there will be mediation, regulation and control of material exchange with nature through human action itself. By transforming nature out of it, man simultaneously transforms his own nature ${ }^{(13)}$. The way (and the context) as (and in what) the work is developed is known as the work process ${ }^{(14)}$, and this is done to somehow achieve a predetermined purpose. The entire work process is governed by this purpose, and it is from this that the criteria and parameters for its realization are established $^{(15)}$. Moreover, in a work process, the purpose is related to meeting the needs and expectations of men, in a given historical and social moment. Work not only produces material goods and services, it also produces workers, their values, their ways of life, their subjectivity ${ }^{(16)}$.

Work produces not only the possibility of realizations of needs, but also of alienation and subordination. The episodes that affect health and disease, which are already the result of the place in society and the capitalist mode of production, also impact the work itself and the activities of daily life, reverberating in a kind of oxymoron (double contradiction).

In the care of those affected by leprosy, especially women, a gender focused on this article, health workers could understand and value these contradictions beyond educational, behavioral, psychic and social aspects, including family and society ${ }^{(2)}$.

When searching the literature, in the databases Medline, LILACS, BDENF, from 2007 to 2017, using the descriptors "women", "leprosy", "work", "woman", "leprosy", "work" and 
"daily activities", no articles were found on the topic. Crossing the descriptors "woman" and "leprosy" in the LILACS database, two articles were found; in BDENF, no article; with the descriptors "women" and "leprosy", in MedLine, 89 articles. Inclusion criteria: article specifically addressing women affected by leprosy; and on the daily life of women with leprosy. At the end of the selection by title and abstract, 12 articles were selected, but none was about the relation with the work. This evidences a shortage of studies focusing on the interference of leprosy in the lives of women in terms of work and activities of daily living, which justifies the present study.

We also did not find studies with the theoretical reference of the work process in health and leprosy in women.

Considering work as a mode of production and reproduction of social places, subjectivities and ways of walking the life and considering leprosy as an important disease that can directly impact the capacity of work and the ways of walking the life, the guiding question of this investigation was: How does leprosy interfere with the work and daily life activities of women being treated?

The present study aims to analyze the interference of leprosy in the lives of women in relation to work and activities of daily living.

\section{METHOD}

\section{Ethical Aspects}

The research was approved by the Research Ethics Committee, according to the provisions of resolution 466/2012 of the National Health Council, and authorized by the School Hospital involved and by the Municipal Health Department. It should also be noted that the participants interviewed signed the Free and Clarified Consent Term (FCCT).

\section{Methodological theoretical reference}

The Analysis was guided by the theoretical reference on leprosy, work process in health and gender ${ }^{(2-4,8-11,17)}$.

\section{Type of study}

A qualitative, exploratory study.

\section{Methodological procedures}

They were carried out from semi-structured interviews and field diaries.

\section{Scenario of study}

The empirical field of the research were the three units that offer treatment for leprosy in an urban municipality of São Paulo considered endemic.

\section{Data source}

The study participants were women affected by leprosy who were being treated in one of the care units for people with leprosy in the municipality. The quantitative study was defined by means of intentional sampling based on the criteria for inclusion and exclusion of the research proposal: women over 18 years of age residing in the studied municipality were being treated. The exclusion criteria were: not to treat municipality, residing in another city and under the age of 18 years. Working conditions (whether or not they have a signed work permit, whether they worked informally or not, as well as whether or not they had housemates) are not included in the participation criteria. A total of 10 women met the inclusion and exclusion criteria and agreed to participate in the study.

\section{Collection and organization of data}

A script was used for the semi-structured interview composed of participant identification data and open-ended questions about the purpose of the study, which involved the life history and the family, the daily routine, the discovery of leprosy and the changes that occurred after the diagnosis in relation to life and work. In addition, the issues raised the dialogue about being a woman and being a carrier of the disease, ways of coping in life, at work and their interference. The interviews took place in the period from May 2016 to July 2017. Initially, the research team requested permission to carry out the research to the coordinator of the unit. She then approached the women attending the aforementioned reference services, who had leprosy (and follow-up) individually, and invited them to participate through the presentation of the research proposal and its objectives. After these steps, the interviews were started and had an average duration of 40 minutes. They were performed at the health service or at the home of the participants themselves, being agreed the guarantee of secrecy and the realization in a private place. The use of the field diary was done to facilitate the apprehension of the existing subjective elements (such as observations of behavior during the interviews, statements of the interlocutors and personal impressions that could be changed during the interview).

As the interviews were recorded on a digital recorder and transcribed in full, it was possible to perform floating readings in search of the content of the material. In the classification of the data, we identified the relevant structures in relation to the analysis of the impact of leprosy on the life of women in what involves work and activities of daily living. Firstly, the thematic units arranged in analytical tables and individually organized by interviewees were selected. After this stage, horizontal syntheses of the interviews were carried out, from the thematic ones, which facilitated the refinement of the empirical material. In this synthesis, the convergences, divergences, complementarities and differences were demarcated. The records of the field diary were thus crossed with the syntheses developed. In the final analysis, the product of the previous steps was interpreted and articulated with the theoretical basis of the study.

\section{Data analysis}

As an organizational strategy for analyzing the empirical material, thematic content analysis was used ${ }^{(18)}$. The subcategories that emerged from the convergences, divergences, complementarities and differences were: the pains of leprosy; changes with disease and adaptations in work and activities; be a woman with leprosy. 


\section{RESULTS}

\section{Characterization of the group}

The group of interviewees was composed of 10 women aged between 24 to 74 years old, among whom 2 were married, 5 were single, 1 was a widow and 1 had a stable union. Regarding schooling, most of the participants had completed high school, only one woman did not finish high school, two of the study participants attended elementary school and one had a postgraduate level. Among the work activities developed by the study participants were: a telephone operator, two cash operators, a production assistant, a day laborer, a general service worker, a biochemical pharmacist, a retiree and one profession is kitchen assistant).

After reading the transcripts of the interviews, the thematic units were delineated and later the categories of analysis, among them: The pains of leprosy; Changes with disease and adaptations in work and activities; and Being a woman with leprosy. The abbreviation "Ent." Was used for "interviewed", followed by Arabic numerals from 1 to 10 , for each woman participating in the survey.

\section{The pains of leprosy}

In the category "Leprosy pains", it was possible to perceive that not only physical pain but also suffering and apprehension with diagnosis and treatment, as well as social pains are illustrated here by the uncertainty of maintaining the conditions of existence, including work.

Physical pain in the person affected by leprosy, as the following statements illustrate, is a common feature and is generally related to the nociceptive stimulus secondary to tissue inflammation or neuropathic cause secondary to damage or dysfunction of the nervous system ${ }^{(19)}$.

My legs ache, right, the nerves, the arms. (Inter. 1)

I was going to work, I was feeling strong pains in my legs, and I even got to get away with leg pains ... (Inter. 3)

If I sit for a long time I feel pain, if I stay a long time I feel pain. (Inter. 9)

Associated with physical pain, we find another form of suffering, which is fear of the reaction of others and shame, which causes people to hide their condition:

[...] My father had too, I accompanied him in everything, but I did not tell anyone [...]. I do not think there's a reason ... I do not say no, because talking is not going to work at all, the only thing that's going to have is that he's going to be scared. (Inter 5)

It's difficult for us to talk because it's not everyone who accepts it, there's a prejudice right ... I did not want my family to suffer [...] Then only my boss who knows, my manager, that I told for them and they said that they would help me, that I did not need to tell my co-workers, that it could be between us ... I was even scared, because leprosy, for those who know it is also the old leprosy, then everyone was afraid to touch things ... I said "there the girls will not even want to sit next to me" [...] and I will not tell, not to spend all the time wondering. (Inter. 6)
All these aspects lead to changes in social relationships that can directly interfere with the way of life, as they promote the isolation and impoverishment of the possible network necessary support for people in difficult situations.

To leave that neither I went out, to jump these things, already in one, in a taste; I was homelier; I insulated myself in the house. (Inter 9)

Only at the beginning I found it much more difficult. It was very, very much ... I did not want to do anything, I did not want to leave. (Inter.6)

\section{Changes with the disease and adaptation at work and daily activities}

In this category, aspects that are directly related to the formal work that sometimes needs adaptation, concern with the loss of productivity, aspects of disrespect to labor rights (strategies for the dismissal) and some reports of work at work are brought forward.

One of the interviewees, divergent, points out that there is no change in their work dynamics:

No, it was not a problem ... not at all. [...] It did not disturb my life in anything, nothing. (Inter. 4)

The others point out changes and difficulties. The changes are mostly represented to these women as related to the physical changes caused by leprosy.

So, when they knew, they immediately sent me to the work doctor. And the doctor at work immediately removed me from handling food ... Then they put me in the refrigerator sector, which is where the yogurts are, those things there ... That is food that is already packaged, you know? [...] And I began to feel the pains in the legs, for climbing stairs only to get products... (Inter. 3)

Another aspect that stands out in the speech of the women is in relation to the decrease of the income in the labor activities, as registered in the speech:

So, I pack the lingerie and now I've already decreased, I was the one that produced more, but I already felt that it is having a fall. (Inter. 6)

[...] I never managed to twist clothes, and I never could do the washing very well ... today I already explain, I will wash it my way, and it has to be a softer bush, so it cannot be that brand new bus. (Inter. 8)

That's the kind of thing I used to do that was crouching, these things I was not doing any more, because of the swollen legs. (Inter.9)

In addition, among the elements present, there are difficulties in formal work and the subtle ways of having the worker voluntarily quit:

[...] Wednesday was my day off, fifth was the rest of the other girl's [...] Fourth, they would get an extra for her and from the fifth they did not get it, I had to work alone, I had 
the lumps in my legs and it was hard for me to work alone. So they were doing on purpose. (Inter. 1)

At work, they at first reacted well, but after a month of treatment, they dismissed me; they simply dismissed me, they did not say why. (Inter 9).

There was mention of the importance of the work of health workers, as well as social support in the care of these women, as in speech:

The new job I got, I went in there, I explained to them that I was in treatment, that it was no longer ... transmissible; the doctor made a letter saying it was not, then the company's doctor accepted and I started to work. (Inter. 9)

\section{Being a woman with leprosy}

In "Being a woman with leprosy", aspects related to a certain expected way of being and being a woman, with defined beauty and aesthetic standards and with leprosy threatening this feminine mode of expression were highlighted. In addition, women pointed to the socially defined role of "mother" as an important factor in coping with the disease:

I think that the fact that we are women and have a lot of faith in things, having to believe, having to raise a child and such, then you accept things and you end up carrying on ...(Inter. 8)

No different from the social and role design, dominant in the report of the women participating in the study, it was reaffirmed convergingly that, from a young age, they were instructed to learn domestic activities, unlike boys:

No. Boys, not men. It was Always me who did everything .... they used to work in the countryside and then helped in the field. At home, it was all with the girls [...] Only the men who did not used to help at home, but we worked on the farm, and also worked at home [laughs]. Now at home, I do not know if it's because we were young and also women, we did not need the men to be helping. (Inter. 5)

The women also reported that the father had no obligation to do the chores:

[domestic service] My father worked a lot, right, and ... his weekend was to rest, he was not going to clean the house, cook, nothing like that; Oh, my mother did. My mother used to work. (Inter.10)

[father does not help with household chores] not at all ... Sometimes yes. Sometimes they can wash a little of the dishes they have at night. But there is also times, that when he does not want it, he does not do anything either. The man thinks he is not obligated to do anything regarding household chores. (Inter. 1)

In view of the above, even in the face of the dissatisfaction of these women, there is an apparent naturalization of the place associated with them in what involves such tasks, as well as of men in the non-fulfillment. Associated with this naturalization, another important aspect is the reproduction, in the discourse of some interviewees, of the victimization of women:
My father is a very sexist person, because he is a man, he cannot do these things [domestic services]; he's a couch potato. (Inter. 9)

I think that because we are women, it gets harder for us. Because women are "all crazy" ya know ... (Inter 1)

So prejudice has two sides, it has the side of someone who has prejudice ... and it has the side of prejudice where he already puts himself in the position of "prejudiced" [refers to people who suffer from prejudice] [...] is not the fact of being a woman, but it is to think that since I am a woman, the other is going to do this, this, and that, then it already takes an attitude of defeat. (Inter. 8)

Still in relation to the naturalization of the aforementioned aspects, despite the strong definition of roles marked in the speeches of these women, it is valid to give visibility to what was revealed by them in relation to the articulation between being a woman and the impact of leprosy. They, in a convergent way, show that they do not perceive differences between men and women affected by the disease (in relation to prejudice) nor in the performance of work activities.

No. I never felt, never had prejudice. (Inter 5)

Anything! always cheerful, never losing the will to do things, never lost. I've always been a warrior. and to me, I do not, I see as leprosy as no problem for me. (Inter. 7)

So, I do not think so. I think this disease there, when you take a person can be a man, a woman ... if you do not treat, you will be deformed. [...] then I think it goes from the head of each one. This man-and-woman business has no difference. (Inter. 9)

\section{DISCUSSION}

In view of the above, it is possible to observe that the occupations of the women interviewed are associated with the professions predominantly related to the female sex, and, for the most part, do not require a high level of education (except one participant, biochemical pharmacist). Starting from the idea that work, in a more generalist conception, is synonymous with access to income, those less valued activities (more frequent among the group of women in the research) are therefore poorly remunerated. In this sense, in order to articulate the theme of work and leprosy, it is possible to understand that the affection, and the statements reinforce this idea ${ }^{(6)}$, is more frequent among the less favored ones, or for reasons of education in health, housing, basic sanitation , among others.

It is important to emphasize that leprosy is treated in public health services, even if the person has medical insurance or private payment conditions. Thus, it may be representative that only one person has college education and profession among the ten participants.

Regarding the time of treatment, 4 of them did not know to accurately inform, the others varied between the 4 th and the 13 th month. Regarding the degree of incapacity, six women did not know how to inform, three were with degree 0 and 
one of them presented degree 1 of incapacity. It should be emphasized that the degree of disability adopted here as a reference is defined by the Ministry of Health ${ }^{(20)}$. Regarding this, it is worth mentioning that the information transmitted to the user about their illness and treatment signals fragility, and this is a problem, since it is an unattended right.

Pain, in general, constitutes a sensation resulting from unpleasant sensory or emotional experience that may vary between people and is related to the social and cultural context. On the other hand, pain (and its intensity) may also be associated with the representation and meaning that the disease assumes for people affected ${ }^{(19)}$. One can also think of social pain, one that comes from inequality and social discrimination. With regard to leprosy, the approach to pain is already beginning at the moment when the diagnosis is received, given the stigma that the disease carries historically.

It is necessary to consider the possible singularities of variables of the subjects involved. For authors, the importance that will be attributed to leprosy will be the result of experiences, since it is submitted to internal influences, according to individual history, and also external, based on the representations of the disease ${ }^{(10)}$. We believe, however, that attributing suffering to biological, physical, and psychological aspects can naturalize aspects that are socially produced.

As the speeches show, the person suffers from the impact of the diagnosis, translated by fear, frustrations and feelings of impotence. Another factor that hinders the process is the difficulty that still exists in services in the definition of diagnosis. Often, the person travels through more than one service until the diagnostic hypothesis of leprosy is raised.

This can be related to the fragmented process of work both in the care network and in health services. Each worker is positioned in a piecemeal stage through the technical division of labor, which is also social. From the researchers' field diary, it was possible to note that medical appointments were the main supply of the follow-up clinics and focused on the aspects of medical diagnosis and treatment of the disease. The other employees of the teams occupy a secondary place, with actions for the medical consultation to occur, for example: pre/post-consultation.

The division of labor is also social, since the work has a distinct social value and demarcates positions in different social classes ${ }^{(21)}$.

It is relevant to highlight that the diagnosis of leprosy is fundamentally clinical and epidemiological, and it is performed by anamnesis and dermatoneurological examination that identifies areas of the skin with changes in sensitivity and/or nerve involvement. Although there is no standard gold standard for diagnosis ${ }^{(22)}$.

With the technological changes in health work, often the clinical diagnoses dependent on light-hard and light technologies are not valued.

It is also important to emphasize that physical pain interferes directly with the performance of work and daily activities. However, the woman's living conditions do not allow absences and dismissal from employment or even failure to perform activities such as washing clothes, cleaning the house, eating meals.
Leprosy then occupies a place of silent pain which, coupled with problems in self-image, directly affects various aspects of women's lives.

A study ${ }^{(10)}$ showed in the drawings of the body image the association made by women between happiness and appearance. That is, in the face of such a relationship, that leprosy marks, such as blemishes and altered skin color, can be signified as unhappiness. Another element that makes this process even more difficult is at a time when the image does not fit the socially accepted standard. This strengthens the prejudice against the disease $\mathrm{e}^{(10)}$. The person with leprosy, as a social subject, reproduces and nourishes stigma and prejudice, which, consequently, hampers even more the process of social understanding and acceptance and of himself. In this sense, it is important to consider that the way to minimize this problem is in social support, which can be provided by family, professionals and health services, as it can come from ${ }^{(3)}$.

This aspect can be verified in study ${ }^{(2)}$ justified by the fear of the possibility of prejudice resulting in abandonment and isolation. Thus, non-sharing is a form of protection ${ }^{(2,8-9,11)}$.

The damages resulting from the stigma that the disease carries also deserve attention. Social, family and even social discrimination ends up allowing the appearance of invisible but irreversible marks that compromise the person's emotional state ${ }^{(11)}$. In addition, along with the history of the disease that is related to episodes of social exclusion and prejudice, the discriminatory posture that some people may adopt inhibits the individuals affected by leprosy, causing them to avoid public and private places and sometimes isolate themselves for fear of rejection ${ }^{(9,11,23)}$.

The overcoming of physical pain can be mitigated by the use of medications ${ }^{(19)}$; however, regarding emotional pain, studies show that family support and good follow-up of the health team offer significant support to the person ${ }^{(2)}$. These aspects are not enough to confront social pain, since they do not touch the basis of production and reproduction of social inequality, they do not debate access to public policies such as education, healthy environment, health, income distribution, among others.

Recently, the Brazilian government approved a Constitutional Amendment ${ }^{(24)}, \mathrm{n} \circ 95$, which freezes and cuts investments in health, education and social programs for the next 20 years. These apparently disconnected measures of people's daily lives generate pain and suffering and certainly impact the quality of life, health, transmission and control of leprosy, the condition of women.

The interviewed women converge to reveal changes in their daily work, even if they are implicit. Such changes reveal the way in which the social context in which leprosy is inserted is also influenced by the incapacities that this disease can generate and repercussions, in addition to the physical contexts, in the psychological, social and economic contexts ${ }^{(8-9)}$.

Thus, coping with the disease, conducting the treatment and even accepting the process can be modified and improved ${ }^{(8)}$.

The discussion about patriarchal brands, about sexist reductions and about all the elements that unfold from these characteristics - such as prejudice, violence and inequality - occurs in the spaces of struggles in Brazilian society and in the world ${ }^{(25)}$. Concern over the gaps left by this brand is real to the point that the debate is the theme at the annual session of the leading global body on gender equality: the UN Commission on the Status of 
Women. By 2017, the priority theme is the economic empowerment of women in the world of work, which is changing ${ }^{(26)}$.

In addition, the issues related to vanity, self-esteem and leisure in the daily life of women affected by the disease and how much there is of significant change in their lives and at work have been previously highlighted.

It is argued here that the woman with leprosy faces a peculiar difficulty associated exactly with her gender condition. The fragilities are in aspects that include the defining roles of their condition: to be beautiful (within a socially defined pattern) and to be able to develop domestic activities, for example.

Domestic work paid or not, in Brazil, is characterized as an activity of women, with an emphasis on the poorest, blackest and least educated. Such activity, when remunerated, is considered to be important in the labor market, especially for low-income workers ${ }^{(25)}$. In this sense, it is known that, in most Brazilian households, such activities are predominantly assumed by the female figure.

With the entrance of the woman into the various spheres of society, this also brought her roles in other social roles, such as mother, wife, domestic, working and also citizen. With this, changes in the behavior and changes in the daily life of this woman happened, as well as have also occurred in social life and health. For the woman, the triple journey can give her feelings that she may not yet know whether they are good or bad, perhaps influenced by the cultural milieu in which she was created or by the society in which she still lives ${ }^{(26)}$.

The psychological and physical complications that can affect people with leprosy, in the context of the activities undertaken by women, undoubtedly have an overload, anguish and a sense of impotence ${ }^{(26)}$. All this, when associated with the naturalization state of what is defined as a female role, for example, and its place in this relationship, makes it more challenging to find strategies that strengthen family and social support relationships, as well as understanding the importance of adoption of other possible ways of living and relating.

\section{Study limitations}

As limit of this study, it is considered the possibility of generalization of results, since qualitative studies do not propose this. However, it presents important aspects for understanding the articulation between leprosy, work and the feminine gender.
Contributions to the area of nursing, health or public policy

The contributions of the study to nursing and health are in the possibility of denaturalizing aspects related to leprosy in women and their impacts on work and living conditions. Nurses and the health and nursing team need to consider the determinants and determinants of health - such as income, work, access to services, schooling, among others - in health care, especially in diseases that are historically neglected as is the case of leprosy. This may qualify the care and help in the indication of public policies for coping with diseases exacerbated by social inequality.

\section{FINAL CONSIDERATIONS}

The study shows that leprosy, its treatment and diagnosis directly impact the work and the daily activities of women. The disease has a great effect on a more visible aspect, which is the production of physical pain, causing productivity to fall and household chores to be done with greater difficulty.

However, there are other social impacts. For example, formal work may be interrupted by dismissal and by measures that make a person resign; and domestic work continues to be attributed to women and is carried out with difficulties, but with a discourse that it is up to them to be strong and continue to do so.

Fragmented and biologically focused health services may consider the impacts of the disease only on the physical or psychological level, when leprosy actually produces pain and impacts in many other aspects that hamper and deepen social inequality, such as isolation and loss of labor and social rights.

\section{FUNDING}

USP Unified Scholarship Program, Support Program for the Training of Teachers and Technicians of the State University of Bahia (PAC-DT UNEB), productivity scholarship CNPq 306190/2014-1.

\section{ACKNOWLEDGMENTS}

We thank the women who were willing to participate in the study, the services that contributed to its accomplishment, to MORHAN, which has been helping in the discussion of leprosy and its care.

\section{REFERENCES}

1. Lourau R. The institutional analysis. 3. ed. Petrópolis: Vozes; 2014.

2. Silveira MGB, Coelho AR, Rodrigues SM, Soares MM, Camillo GN. Hansen's disease patients: psychological impact of the diagnosis. Psicol Soc[Internet]. 2014[cited 2017 Jul 27];26(2):517-27. Available from: http://www.scielo.br/pdf/psoc/v26n2/ a27v26n2.pdf

3. Monte RS, Pereira MLD. Hansen's disease: social representations of affected people. Rev Rene [Internet]. 2015 [cited 2017 Jul 27];16(6):863-71. Available from: http://www.repositorio.ufc.br/handle/riufc/14772

4. Dominguez B. Hanseníase: problema persistente. Rev Radis [Internet]. 2015[cited 2017 Jul 27];150:24-6. Available from: http:// www6.ensp.fiocruz.br/radis/revista-radis/150/reportagens/problema-persistente

5. Lopes VAS, Rangel EM. [Leprosy and social vulnerability: an analysis of the socioeconomic profile of users in irregular treatment]. Saúde Debate [Internet]. 2014[cited 2017 Jul 27];103(38):817-29. Available from: http://www.scielo.br/pdf/sdeb/ 
v38n103/0103-1104-sdeb-38-103-0817.pdf Portuguese

6. Vasconcelos RS, Kovaleski DF, Junior ZCT. Neglected diseases: literature review on intervention proposals. Saude Transf Soc[Internet]. 2016[cited 2017 Jul 27];6(2):114-31. Available from: http://incubadora.periodicos.ufsc.br/index.php/saudeetransformacao/article/ view/3714

7. Reis ACSM, Borges DPL, D'Ávila VGFC, Barbosa MS, Ternes YMF, Santiago SB, et al. O cenário de políticas públicas do brasil diante do quadro das doenças negligenciadas. Saúde Ciênc Ação [Internet]. 2017[cited 2017 Jul 27];3(1):99-107. Available from: http://revistas.unifan.edu.br/index.php/RevistalCS/article/viewFile/237/179

8. Loures LF, Mármora CHC, Barreto J, Duppre NC. Perception of stigma and social impacts on individuals with hansen's disease. Psicol Estudo [Internet]. 2016[cited 2017 Jul 27];21(4):665-75. Available from: http://www.redalyc.org/pdf/2871/287149565012.pdf

9. Leite SCC, Sampaio CA, Caldeira AP. "Like rust on an old tin can": The discourses of stigma of institutionalized patients with leprosy. Physis [Internet]. 2015[cited 2017 Jul 27];25(1):121-38. Available from: http://www.scielo.br/pdf/physis/v25n1/01037331-physis-25-01-00121.pdf

10. Batista TVG, Vieira CSCA, Paula MAB. Body image in educational actions in self-care for people who had leprosy. Physis [Internet]. 2014[cited 2017 Jul 27];24(1):89-104. Available from: http://www.scielo.br/pdf/physis/v24n1/0103-7331-physis-24-01-00089.pdf

11. Esquivel CB, Moreira FF, Atalla SA. Qualidade de vida em mulheres que foram atingidas pela hanseníase. Multitemas [Internet]. 2016[cited 2017 Jul 27];(25):41-9. Available from: http://www.multitemas.ucdb.br/article/view/839/814

12. Codo W. Um diagnóstico do trabalho (em busca do prazer). In: A. Tamayo, J. Borges-Andrade \& W. Codo (Eds.). Trabalho, organizações e cultura. São Paulo: Cooperativa de Autores Associados; 1997 p.21-40.

13. Marx K. O Capital: crítica da economia política. Livro I: O processo de produção do capital. Trad. Rubens Enderle. São Paulo: Boitempo; 2013.

14. Brito GEG, Mendes ACG, Santos NPM. Purpose of work in the Family Health Strategy. Interface [Internet]. 2017 [cited 2017 Jul 27]. Available from: http://www.scielo.br/pdf/icse/2017nahead/1807-5762-icse-1807-576220160672.pdf

15. Faria HP, Werneck MAF, Santos MA, Teixeira PF. O processo de trabalho e seus componentes [Internet]. Universidade de Minas Gerais. Faculdade de Medicina UFMG. Núcleo de Educação em Saúde Coletiva. [cited 2017 Jul 27]. Available from: https://www. nescon.medicina.ufmg.br/biblioteca/imagem/4247.pdf

16. Abrahão AL, Merhy EE. Healthcare training and micropolitics: concept tools in teaching practices. Interface [Internet]. 2014[cited 2017 Jul 27];18(49):313-24. Available from: http://www.scielo.br/pdf/icse/v18n49/1807-5762-icse-18-49-0313.pdf

17. Fontana KC, Lacerda JT, Machado PMO. Work Process in Primary Health Care: evaluation of management. Saúde Debate [Internet]. 2016[cited 2017 Jul 21];40(110):64-80. Available from: http://www.scielo.br/pdf/sdeb/v40n110/0103-1104-sdeb-40-110-0064.pdf

18. Bardin L. Content analysis. São Paulo: Edições 70, 2012.

19. Arco RD, Nardi SNT, Bassi TG, Paschoal VDA. Diagnosis and medical treatment of neuropathic pain in leprosy. Rev LatinoAm Enfermagem [Internet]. 2016[cited 2017 Jul 27];24:e2731. Available from: http://www.scielo.br/pdf/rlae/v24/pt_0104-1169rlae-24-02731.pdf

20. Brasil. Ministério da Saúde. Portaria Conjunta n 125, de 26 de março de 2009. Define ações de controle da hanseníase. Anexo III. Formulário para avaliação do grau de incapacidade física[Internet]. Diário Oficial da União. 2009[cited 2017 Jul 27]. Available from: http://bvsms.saude.gov.br/bvs/saudelegis/svs/2009/poc0125_26_03_2009.html

21. Rodrigues D. Marx e a divisão social do trabalho, uma resposta atual. IV Conferencia Internacional. La obra de Carlos Marx y los desafíos del siglo[Internet]. 2016[cited 2017 Jul 27];8(2);1-5. Available from: https://www.nodo50.org/cubasigloXXI/congreso08/ conf4_rodriguesd.pdf

22. Alves ED, Ferreira TL, Nery I. Hanseníase: avanços e desafios. Brasília: NESPROM [Internet]. 2014 [cited 2017 Jul 27$]: 492$. Available from: http://www.nesprom.unb.br/9-noticias/19-hanseniase-avancos-e-desafios\#.WXj-TYTyvIU

23. Brasil. Ministério da Saúde. Secretaria de Vigilância em Saúde. Departamento de Vigilância Epidemiológica. Leprosy and Human Rights: Unified Health System (SUS) Users Rights and Moral Obligations. Série F. Comunicação e Educação em Saúde. Brasília. 2008:72.

24. Brasil. Constituição de 1988. Emenda Constitucional n. ${ }^{095}$, de 16 de dezembro de 2016. Altera o Ato das Disposições Constitucionais Transitórias, para instituir o Novo Regime Fiscal, e dá outras providências. Diário Oficial [Internet]. 2016 [cited 2017 Jul 27];241:2. Available from: http://pesquisa.in.gov.br/imprensa/jsp/visualiza/index.jsp?jornal = 1 \&pagina =2\&data =16/12/2016

25. Bandeira LM. Violência de gênero: a construção de um campo teórico e de investigação. Soc Estado [Internet]. 2014 [cited 2017 Jul 27];29(2). Available from: http://www.scielo.br/pdf/se/v29n2/08.pdf

26. Carvalho L. "Diante de um ambiente econômico incerto, empoderar as mulheres no trabalho é a chave", afirma diretora regional da ONU Mulheres Américas e Caribe. ONU mulheres [Internet]. 2017[cited 2017 Jul 27]. Available from: http://www.onumulheres. org.br/noticias/artigo-diante-de-um-ambiente-economico-incerto-empoderar-as-mulheres-no-trabalho-e-a-chave-afirma-diretoraregional-da-onu-mulheres-americas-e-caribe/ 